\title{
Patriotyzm według Józefa Marii Bocheńskiego
}

\section{Patriotism according to Józef Maria Bocheński}

\section{Streszczenie:}

Celem tego artykułu jest zwrócenie uwagi na zagadnienie patriotyzmu, tak jak było ono postrzegane przez Józefa Marię Bocheńskiego - polskiego filozofa, duchownego i żołnierza. Najpierw zostaje pokrótce przedstawiona postać J. M. Bocheńskiego oraz jego wspomnienia z okresu dzieciństwa opisujące między innymi rodziców i rodzeństwo. Następnie opisane zostaje przedwojenne pojmowanie patriotyzmu w Polsce, które miało wpływ na ukształtowanie się poglądów Bocheńskiego w tym obszarze. Dalej zostaje opisana struktura patriotyzmu, którą prezentuje myśliciel oraz jego wielowątkowość i obowiązki jakie posiada każdy człowiek wobec swojej ojczyzny. W zakończeniu wskazuje się, że jest to próba rekonstrukcji drobnego fragmentu z bogatej twórczości myśliciela.

Słowa kluczowe: patriotyzm, ojczyzna, obowiązki wobec ojczyzny, dwudziestolecie międzywojenne, polska myśl patriotyczna, wychowanie patriotyczno-obywatelskie

\section{Abstract:}

The aim of the article is to draw attention to the problem of patriotism as it was perceived by Józef Maria Bocheński - a Polish philosopher, priest, and soldier. First, the figure of J. M. Bocheński is concisely sketched, as well as his 
Łukasz Cieślakowski - Patriotyzm według...

reminiscences from childhood - evoking among other his parents and siblings. Then, the understanding of patriotism in the pre-1939 Poland is presented since it influenced Bocheński's views in that area. Next, following Bocheński's texts, the structure of patriotism is shown, including its multilayered characteristic and the duties each man has towards his country. In the conclusion it is put forward that the article is an attempt to reconstruct only a little part of the rich work of the thinker.

Keywords: patriotism, country, duties towards the country, the period 1918-1939, the Polish patriotic ideas, the patriotic and citizen education

\section{Wstęp}

W polskiej myśli filozoficznej swoje miejsce wyraźnie zaznaczył dominikanin, o. Józef Maria Bocheński. Jego prace dotyczące głównie logiki (zajmował się on także zagadnieniami patriotyzmu, marksizmu etc.) zostały docenione nie tylko w Europie ale także na świecie. Warto wspomnieć o licznych przekładach prac Bocheńskiego na różne języki, które nie ograniczały się wyłącznie do tych najpopularniejszych (niemiecki, angielski, francuski). Zdaje się być on godnym podziwu także ze względu na wielość ról jakie pełnił w swoim życiu. Był on bowiem żołnierzem, duchownym i uczonym. Walczył z Grupą Operacyjną „Pomorze”, a także z II Korpusem generała Andersa pod Monte Casino, po 1945 roku osiadł we Fryburgu w Szwajcarii i nauczał na tamtejszym uniwersytecie, którego zresztą był także rektorem. W późniejszym czasie stworzył także Instytut Europy Wschodniej, który to był przodującą placówką na świecie zajmującą się badaniem filozofii panującej w Związku Radzieckim i państwach od niego zależnych.

Celem Instytutu Europy Wschodniej były badania nad stanem filozofii w ZSRR oraz w krajach Bloku Wschodniego, przy czym w centrum jego uwagi leżała myśl marksistowsko-leninowska. Instytut Bocheńskiego był placówką uniwersytecką. Stanowił przez wiele lat jedyny naukowy ośrodek filozoficznych studiów filozoficznych. Starano się tu przede wszystkim filozofię rosyjską poznać, a jej krytykę ograniczyć do aspektu wyłącznie naukowego, nie wdając 
się w żadne dyskusje ideologiczne. Instytut miał za zadanie wykształcenie znawców marksizmu-leninizmu, których na Zachodzi było brak ${ }^{1}$.

Filozof ten wywarł duży wpływ także na postrzeganie patriotyzmu - tego, który mogliśmy obserwować kiedyś, a który w dzisiejszych czasach nabiera nowego znaczenia, chociaż jego pewne elementy są podobne. $\mathrm{W}$ tym miejscu należy postawić pytanie, czym ów patriotyzm jest i dlaczego tak właśnie postrzegany był on przez Bocheńskiego? Myślę, że to pytanie jest bardzo szerokie, także ze względu na wielość doświadczeń jakie zdobył on podczas swojego życia - należy pamiętać, że był żołnierzem, duchownym i filozofem, uczestniczył w wojennej zawierusze, wykładał na uniwersytetach całego świata, a przede wszystkim był emigrantem - nie powrócił do Polski ze względu na system panujący w kraju po zakończeniu II wojny światowej. Ze względu na wspomnianą „wielość” niemożliwa staje się jednoznaczna odpowiedź na postawione pytanie czym tak naprawdę jest patriotyzm. Postaram się jedynie nakreślić pewną ścieżkę, którą można podążyć i niejako przypatrzyć się temu co zostało przez nas zastane, pozostawione nam przez Józefa Bocheńskiego. W pracy tej dokonam konfrontacji poglądów Józefa Bocheńskiego na temat patriotyzmu do poglądów powszechnych w XX-leciu międzywojennym. Sprawdzę jakie relacje zachodziły między dwoma niekiedy różnymi, niekiedy zbieżnymi stanowiskami reprezentowanymi przez Bocheńskiego i międzywojennych myślicieli. Jednak zanim to nastąpi pokrótce należy przedstawić krótką biografię interesującej nas postaci.

\section{Nota biograficzna}

Ojciec Józef Maria Bocheński (właściwie Józef Franciszek Emanuel Bocheński) urodził się 30 sierpnia 1902 roku w Czuszowie. Miejsce jego narodzin, geograficznie, jak sam pisze w swoich wspomnieniach, opisać można następująco: „urodziłem się w Czuszowie, w powiecie

\footnotetext{
${ }^{1}$ K. Policki, Filozofia człowieka we wczesnej twórczości J. I. M. Bocheńskiego OP, Wrocław 2005, s. 60.
} 
Łukasz Cieślakowski - Patriotyzm według...

miechowskim, w ziemi kieleckiej, a więc w dawnym zaborze rosyjski, niedaleko od Krakowa"2. Jednakże nie spędził on tam swojego dzieciństwa, bowiem gdy miał cztery lata jego rodzice przeprowadzili się do miejscowości Ponikwy, która w tamtym czasie należała do Galicji Wschodniej. Jego dom rodzinny budził u Bocheńskiego żywe wspomnienia - nie tylko ze względu na wydarzenia, które miały tam miejsce oraz chwil spędzonych wraz z najbliższymi ale także ze względu na to jak on wyglądał. Tak we Wspomnieniach go opisuje:

\begin{abstract}
Budynek główny, w którym żyliśmy, zaczynał się od strony stawu potężna okrągłą czteropiętrową wieżą, przed którą jednopiętrowa przybudówka zawierająca trzy pokoje. Dalej budynek był parterowy i zawierał tylko sześć wielkich pokojów: ze strony wejścia od strony stawu przedpokój, kancelarię mojego ojca i jeszcze jeden wielki pokój, którego nazwy nie pomnę, z drugiej strony sala jadalna, salon i bilard. Ostatni człon tego budynku był jednopiętrowy i zawierał na parterze tak zwany zimny salon [...] a po drugiej stronie wejścia pokój dzieciny, sypialnię rodziców i dużą łazienkę [...] Muszę przyznać, że trudno było żyć w takim budynku, który był całkiem oczywiście pomyślany jako ramy dla paradnych przyjęć, nie dla codziennego życia, o które budowniczowie tego domu widocznie niewiele dbali3 ${ }^{3}$.
\end{abstract}

Niemały wpływ na późniejsze działania oraz poglądy filozofa miała jego rodzina. Prócz ojca oraz matki w jego życiu obecni byli także dwaj bracia (Adolf i Aleksander) a także siostra (Olga). Jak pisał „siostra i ja [Józef Bocheński] wdaliśmy się fizycznie w matkę, a obaj bracia Aleksander i Adolf byli raczej podobni do ojca. Różniliśmy się między sobą znacznie - myślę, że każde z nas było dość swoistym typem"4.

Nie mylił się pisząc o swojej rodzinie właśnie w ten sposób. Każdy członek jego rodziny stanowił indywiduum. Józef Bocheński swojego brata Aleksandra wspomina w następujący sposób:

Aleksander jest jednym z najbardziej oryginalnych pisarzy politycznych swojego pokolenia. Aby tylko jedno wymienić, jest bodaj jedynym Polakiem, który jednocześnie przyznawał się na serio do wiary katolickiej i do równie szczerej przyjaźni względem Moskwy bolszewickiej, tak dalece, że nawet najinteli-

\footnotetext{
2 J. Bocheński, Wspomnienia, Kraków 1994, s. 19.

3 Ibidem, s. 21.

4 Ibidem, s. 16.
} 
gentniejsi komuniści nie wiedzieli, co z nim począć [...] Był też nie tylko wybitnym przemysłowcem, przez jakiś czas dyrektorem browaru oświęcimskiego, ale i czołowym historykiem przemysłu polskiego, posłem na sejm PRL itp. ${ }^{5}$.

Z powyższego cytatu wynika, iż Aleksander Bocheński, podobnie jak jego brat Józef, był człowiekiem wierzącym. Jednak w odróżnieniu od Aleksandra, Józef „nie pałał miłością” do naszych wschodnich sąsiadów. Można powiedzieć wręcz, że było zupełnie inaczej.

Brat Adolf był dla Józefa wzorem waleczności i poświęcenia. Możliwe, że to także jego życie wpłynęło na to w jaki sposób Józef Maria, w swojej późniejszej twórczości postrzegał patriotyzm, obowiązek miłości ojczyzny, a także to, w jaki sposób rozpatrywał on wojnę i potrzebę obrony swojego kraju matczynego.

Adzio jest postacią niemal legendarną jako żołnierz - i nic dziwnego. Wziął udział we wszystkich kampaniach dostępnych Polakowi: w polskiej, norweskiej, francuskiej, afrykańskiej i włoskiej. Przeprowadził szereg naprawdę niezwykłych akcji bojowych zdobywając Virtuti Militari i dwa razy Krzyż Walecznych [...] Był przede wszystkim wielkiej klasy intelektualistą francuskiego typu, nieprawdopodobnie wprost oczytanym, o niezwykle szerokich zainteresowaniach kulturalnych ${ }^{6}$.

Nie sposób nie zatrzymać się na chwilę przy tych słowach. Z opisu Adolfa przedstawionego przez Józefa Bocheńskiego wynika, iż jego brat był wzorem do naśladowania, reprezentował takie cnoty, które powinien prezentować każdy, kto miłuje ojczyznę. Domyślać się można (także ze wspomnień Józefa Bocheńskiego), że Adolf wywarł spory wpływ na to, w jaki sposób postrzegał patriotyzm oraz obowiązki patriotyczne.

Oprócz dwóch braci Józef Bocheński miał także siostrę Olgę. Niewiele o niej wspominał, napisał kiedyś, że żałuje, iż nie zżył się z nią, tak jak ze swoimi braćmi. Jednak w jego wspomnieniach Olga była bardzo religijną kobietą, co - jak zauważa Bocheński - odziedziczyła po matce. Jeżeli chodzi rodziców to z pewnością mieli duży wpływ na

\footnotetext{
5 Ibidem.

6 Ibidem, s. 17.
} 
to, kim stał się opisywany filozof. We Wspomnieniach zapisał: „Mój ojciec Adolf wywarł na mnie, o ile mogę zdać sobie z tego sprawę, znacznie większy wpływ niż moja matka"7. Możliwe, że twierdzi tak także dlatego, że podobnie jak ojciec, poświęcił się on nauce. Jego ojciec, urodzony w 1870 r. w Warszawie, studiował ekonomię polityczną w Getyndze, gdzie uzyskał w roku 1894 doktorat ${ }^{8}$. Jeżeli chodzi o światopogląd, ojciec Bocheńskiego w pamięci swojego syna: „był typowym inteligentem XIX wieku, wyznawcą Oświecenia, wierzył w postęp ludzkości przez światło nauki. To jednak bez śladu fanatyzmu, tak zresztą jak jego głęboki, ale pełny umiaru patriotyzm”. Swoją matkę opisuje zaś następującymi słowami:

[...] charakter mojej matki określa się najlepiej mówiąc, że była to władcza natura, kobieta obdarzona niezłomną wolą, żelaznym charakterem. Górowała nad swoim otoczeniem, rządziła bezapelacyjnie moim ojcem, nami dziećmi i dworem. Zarazem to była postać feudalna, jakby żywcem przeniesiona w nasze czasy ze średniowiecza [...] Była gorliwą i surowo umartwioną tercjarką karmelitanek bosych. Głęboko wierząca, żyła wyłącznie dla Służby Bożej10.

Matka Bocheńskiego - Maria, zdecydowanie przyczyniła się do zaszczepienia w swoim synu wartości religijnych i patriotycznych, należy pamiętać, że to właśnie ona dbała o to, aby w każdą niedzielę oraz święta jej dzieci uczestniczyli we mszy, którą odprawiał zaprzyjaźniony z rodziną Bocheńskich kapłan. Warto także pamiętać o tym, iż mimo, że nie miała ona wielkiego wpływu na „sprawy naukowe”, to w swoim dorobku posada także kilka tłumaczeń z języka francuskiego.

Józef Maria Bocheński doceniany był na całym świecie - wspomnieć należy o tym, że był mile widzianym gościem na amerykańskich uniwersytetach i toczył żywe polemiki z tamtejszymi filozofami, logikami i innymi. Niestety w Polsce, ze względu na panujący system, do roku 1989 nie był powszechnie znany, być możliwe dlatego, że był

\footnotetext{
7 Ibidem, s 12.

8 Ibidem.

9 Ibidem, s. 14.

10 Ibidem, s. 15.
} 
zaciekłym przeciwnikiem komunizmu, podkreślając wyraźnie to, że jego ukochany kraj został wyzwolony spod okupacji niemieckiej jednak nie odzyskał on wolności. Po przemianach, które nabrały szybkości po roku 1989, prace filozofa trafiły pod polskie „strzechy”. Oczywiście nie stało się to natychmiast i nie wszystkie jego prace nie były od razu dostępne w języku polskim, jednak nastąpił pewien przełom. Niewątpliwie coraz większy dostęp do prac bocheńskiego sprawia, że społeczeństwo lepiej go poznaje. Dodatkowo różnego rodzaju wypowiedzi ukazujące się $\mathrm{w}$ prasie wspomagają szerzenie wśród narodu myśli dominikanina. Przykładem takiej wypowiedzi prasowej może być tekst Stanisława Lema, zamieszczony w jednym z numerów Tygodnika Powszechnego (społeczno-kulturowy tygodnik katolicki), który ukazał się w 1996 roku. Możemy w nim znaleźć między innymi taki opis:

Niezwykła była ta osoba i obdarzona tyloma rozmaitymi umiejętnościami! Rocznik 1902, kawalerzysta w czasie wojny polsko-bolszewickiej, kampanię włoską podczas II wojny światowej spędził u boku biskupa Gawliny. Świat cały objeździł, ziemię opasał kilometrami swych podróży, znał osobiście wszystkich wybitnych logików i filozofów - a przy tym nosił mniszą sukienkę. Po osiemdziesiątce latał jeszcze sportowym samolotem, a egzaminy na pilota zdawał, mając lat siedemdziesiąt. Nie całkiem skromne, choć trochę ironiczne jest jego powiedzenie, że na autostradach w Ameryce nigdy nie przekraczał szybkości $250 \mathrm{~km}$ na godzinę 11.

W podobny sposób filozofa wspomina Stefan Norkowski, który ponad dwa lata pełnił funkcję osobistego lekarza Józefa Bocheńskiego - $w$ jego wspomnieniach myśliciel jawi się następująco:

Długo można by opowiadać o ojcu Bocheńskim. Gdybym musiał jednak w jednym zdaniu streścić wszystko, co najważniejsze odnośnie do jego osoby, powiedziałbym, że był to człowiek niezależny w myśleniu, niepohamowany w swojej aktywności badacza tajemnic świata, nacechowany prawdziwym zachwytem nad Bożym dziełem stworzenia i renesansową radością z powodu możliwości ludzkiego uczestnictwa w tym dziele przez rozwój nauki i tech-

11 K. Policki, Filozofia człowieka..., op. cit., s. 30. 
Łukasz Cieślakowski - Patriotyzm według...

niki, gorący polski patriota i lojalny obywatel Szwajcarii, zatroskany o duchową przyszłość naszego większego domu - Europy ${ }^{12}$.

Józefa Bocheńskiego wspominają także wybitni naukowcy, do jakich niewątpliwie zalicza się profesor (były dziekan Uniwersytetu Jagiellońskiego) Władysław Stróżewski, który tak oto opisuje postać filozofa:

O. Bocheński odznaczał się wielką intelektualną odwagą. Podejmował problemy trudne i nie wahał się proponować kontrowersyjnych rozstrzygnięć. Nie bał się polemik i dyskusji, nie bał się narażać takim, czy innym autorytetom. Zdawał sobie doskonale sprawę z wagi tradycji, z jakiej wyrósł, ale filozofował na własną odpowiedzialność, dystansując się także i od tego, co w przeszłości było mu bliskie ${ }^{13}$.

Kończąc tę część, warto odnieść się do obszernego fragmentu przedmowy zamieszczonej w książce ks. Korneliusza Polickiego Filozofia człowieka we współczesnej twórczości J. I. M. Bocheńskiego OP, której autorem jest bp Ignacy Dec. Wyrażony jest w niej podziw dla działalności J. M. Bocheńskiego ale również ubolewanie nad tym, że w Polsce - zwłaszcza takiej jaką teraz znamy, myśl Bocheńskiego nie znalazła (mimo swojej wartości i trafności) ogólnej aprobaty i tego, że nie jest dostatecznie dobrze znana szerszym kręgom odbiorców.

[...] myśliciel był przez 5 lat profesorem w rzymskim Angelicum oraz 27 lat na Uniwersytecie we Fryburgu. Wykładał co najmniej jeden semestr na dwunastu uniwersytetach: w Europie, Ameryce Północnej, Ameryce Południowej i w Afryce. Był dwukrotnie dziekanem Wydziału Filozoficznego i rektorem Uniwersytetu we Fryburgu Szwajcarskim. Otrzymał 5 doktoratów honorowych. Odbył 35 międzykontynentalnych podróży, przelatując 53 razy oceany jako pilot. Jego dorobek naukowy obejmuje 90 tomów. Bocheński poprzez swoje prace, szczególnie z pierwszego okresu swej twórczości, przyczynił się wydatnie do rozkwitu neotomizmu w Polsce i na Zachodzie. W latach międzywojennych, wraz z ks. Janem Salamuchą i Franciszkiem Drewnowskim, należał do tzw. Koła Krakowskiego, które podjęło program uściślania klasycznej filozofii i teologii za pomocą narzędzi współczesnej logiki. Jego ABC tomizmu do dzisiaj nic nie straciło na aktualności. Idee Bocheńskiego rozwijane w jego

\footnotetext{
12 Ibidem.

13 Ibidem, s. 29.
} 
wczesnej działalności naukowej można [...] odnaleźć w encyklice Jana Pawła II Fides et ratio. Wielka szkoda, że myśl Bocheńskiego, zwłaszcza antropologiczna, nie jest dostatecznie znana w Polsce. Złożyło się na to wiele powodów, m.in. długoletni powojenny zakaz publikowania jego dzieł w naszym kraju14.

Z powyższej wypowiedzi łatwo wywnioskować, że ojciec Bocheński postrzegany jest jako osoba światła, wszechstronnie wykształcona, poważana. Istnieje jednak pewien niedosyt spowodowany tym, że dopiero od 26 lat w Polsce możemy mieć szerszy kontakt $\mathrm{z}$ jego twórczością. Ponadto warto zauważyć, że od publikacji książki Polickiego minęło 10 lat, to nadal dzieła Bocheńskiego nie są powszechnie znane, co nie jest optymistycznym zjawiskiem.

\section{Przedwojenne pojmowanie patriotyzmu}

Odnosząc się do wypowiedzi profesora Stróżewskiego dotyczącej świadomości Bocheńskiego tradycji, z której wyrastał, warto chociaż pokrótce zapoznać się, jak niegdyś postrzegany był patriotyzm. Myślę, że takie rozważania należy rozpocząć od encyklopedycznej definicji pojęcia „patriotyzm”. Zgodnie Encyklopediq Powszechnq Ilustrowanq z 1911 roku:

Patriotyzm (z łac. - partia - ojczyzna) - miłość ojczyzny. Patrjotyzm jest największą cnotą obywatelską. Człowieka o gorącem uczuciu patrjotycznem nazywamy patrjotą; patrjotycznem jest wszystko, co świadczy o patrjotyzmie i z niego wynika ${ }^{15}$.

Powyższa definicja jest bardzo lakoniczna i zagmatwana. Czytając ją ma się wrażenie, że "to samo, wynika z tego samego" - wedle owej definicji patriotyzm to wszystko, co jest patriotyczne. Być może lepszy ogląd tego, czym według ówczesnych, był patriotyzm, zdobędziemy gdy zagłębimy się w treści przekazywane w seminariach nauczycielskich, a odnoszących się do tego, jak nauczyciele mają kształtować postawy patriotyczne i pielęgnować w swoich podopiecznych miłość

\footnotetext{
14 Ibidem, s. 5.

15 Encyklopedia Powszechna Ilustrowana, Tom III, Warszawa 1911.
} 
Łukasz Cieślakowski - Patriotyzm według...

do ojczyzny. W podręczniku Mieczysława Baranowskiego można odnaleźć następujące treści dotyczące kształcenia patriotyzmu oraz miłości ojczyzny:

Miłość ojczyzny usposabia życzliwie dla współbraci i jest warunkiem szczęścia i rozwoju państw i społeczeństw. Tylko te narody kwitną i postępują, gdzie miłość ojczyzny ożywia wszystkich obywateli [...] Sumienne spełnianie obowiązków obywatelskich w gminie, kraju i państwie są naturalnem następstwem dobrze pojętego patryotyzmu [...] Miłość ojczyzny powinna się objawiać w czynach, a nie tylko w słowach - dlatego tylko czynną miłość ojczyzny, objawiającą się wytrwałą i skuteczną pracą dla dobra publicznego, w umysły młodzieży zaszczepiać należy [...] Nauka języka i jego literatury, nauka dziejów ojczystych i geografii ziemi ojczystej, śpiewy ojczyste, zwiedzanie różnych dzielnic ziemi ojczystej i jej pamiątek, a nade wszystko szczery i prawdziwy patryotyzm rodziców i wychowawców - oto środki, które znakomicie wpływają na rozwój i uszlachetnienie uczuć patryotycznych młodzieży16.

Podobne podejście do poruszanej przeze mnie tematyki patriotyzmu odnaleźć można w podręczniku z 1918 roku, w którym odnajdujemy następujące stwierdzenia:

Wychowanie ma następnym pokoleniom podać spuściznę poprzednich całą i nienaruszoną i uzdolnić je do jej utrzymania i pomnożenia. Do tej zaś spuścizny należy w pierwszym rzędzie narodowość jako jedno z najstarszych i najświętszych dóbr. Obowiązkiem tedy wychowania rozwijać i pielęgnować w młodem pokoleniu zarody narodowości i miłości Ojczyzny. Jest to uczucie sympatyczne, rozciągające się już nie tylko na rodzinę i najbliższych, lecz na cały kraj i naród; jest to żywe odczuwanie szczęścia lub nieszczęścia Ojczyzny, co pięknie wyraził Mickiewicz: Szczęścia w domu nie znalazł, bo go nie było w Ojczyźnie (Konrad Wallenrod); jest to silne pragnienie, aby być Ojczyźnie użytecznym, służyć jej w pokoju, a bronić w niebezpieczeństwie. Jest to uczucie wrodzone i pierwotnie objawia się jako tęsknota do rodzinnego domu, zagonu i wioski (t. zw. nostalgia); później, dzięki uświadomieniu, podnosi się na wyższy szczebel szerszej, czystej miłości Ojczyzny17.

16 M. Baranowski, Pedagogika do użytku seminaryów pedagogicznych i nauczycieli szkół ludowych, Warszawa-Lublin-Łódź-Poznań-Kraków 1921, s. 67.

17 W. Kosiński, Pedagogika podręcznik dla wychowawców i nauczycieli, PoznańWarszawa 1918, s. 204. 
Z powyżej zacytowanych fragmentów przedwojennych podręczników oraz encyklopedii wynika jasno, że na patriotyzm składa się wiele składników, do których zaliczano między innymi dobro publiczne, kulturę, naród i kraj. Bocheński w swoich rozważaniach na temat patriotyzmu także odwoływał się do tych pojęć. Podkreślał również wielość czynników, jakie wpływają na odczucia patriotyczne w przedstawicielach narodu polskiego. Często odwoływał się także do podstaw miłości do ojczyzny, czyli kraju i narodu - bowiem co innego mielibyśmy miłować rozpatrując omawiane uczucia.

W cytowanej pracy Wacława Kosińskiego odnaleźć można także wskazówki do pojęcia tego, kto i dlaczego powinien dawać przykład miłości ojczyźnianej młodym ludziom. Wskazuje on jasno, że dwoma podstawowymi wzorcami powinni być rodzice oraz wychowawcy. Ponadto przywołany autor opisuje, czym według niego patriotyzm nie jest - a nie można do niego zaliczyć szowinizmu oraz kosmopolityzmu.

Przykład patrjotyzmu winni dawać rodzice i wychowawcy. Zawsze z zapałem i uwielbieniem winni się odzywać o Ojczyźnie, jej dziejach, jej instytucjach; winna też młodzież poznać życiorysy wielkich miłośników Ojczyzny [...] Zdrowy, czysty patriotyzm nie ma nic wspólnego z nienawiścią innych narodów, t. zw. szowinizmem; jest on przeciwieństwem obojętności na sprawy ojczyste, t. zw. kosmopolityzmu18.

W pracach Józefa Marii Bocheńskiego widać wyraźne ślady owych przedwojennych poglądów na temat patriotyzmu i miłości do ojczyzny. Tak jak cytowani powyżej autorzy zwraca on uwagę na to, że świadomość narodowa i poczucie przynależności do danej społeczności jest podstawą opisywanego uczucia. Patriotyzm w myśli Bocheńskiego jest także wartością, która połączona jest z moralnością człowieka. W jednym ze swoich tekstów filozof wyjaśnia, czym są wartości - wymienia trzy ich rodzaje: wartości moralne (najlepiej poznane przez filozofów), estetyczne oraz religijne. Te pierwsze w postrzeganiu oraz pojmowaniu patriotyzmu wdają się być szczególnie istotne,

18 Ibidem, s. 205. 
gdyż „ich swoistą cechą jest domaganie się czynu [...] tkwi w nich pewna powinność czynu, a nie jedynie powinność istnienia"19. Moim zdaniem idealnie pasuje to do tego, co mogliśmy odnaleźć w podręcznikach Pedagogika do użytku seminaryów pedagogicznych i nauczycieli szkół ludowych oraz Pedagogika podręcznik dla wychowawców i nauczycieli. Nie można bowiem wyłącznie wymagać, aby ktoś kochał swoją ojczyznę, kraj, naród. Zgodnie z wartościami moralnymi trzeba działać zgodnie z tym jak postępujemy, nie możemy działać w oderwaniu od naszych oczekiwań względem innych. Czyn patriotyczny wedle powyższego jest obowiązkiem w przypadku kierowania się wartościami moralnymi i chęci egzekwowania miłości ojczyźnianej od innych.

\section{Przedmiot odniesień postaw patriotycznych - Ojczyzna}

Rozpatrując to, jak Bocheński postrzegał patriotyzm, w pierwszej kolejności trzeba zaznaczyć, że sam myśliciel podkreślał, że to, co kryje się za słowem „patriotyzm”, nie jest do końca jasne i istnieje wiele sporów na ten właśnie temat. W swojej rozprawie $O$ patriotyzmie pisał:

Istnieje dość zawiły spór na temat przedmiotu patriotyzmu, czyli znaczenia słowa „ojczyzna”. Spór ten nie tylko nie został rozstrzygnięty [...] ale nie ma odnośnie do niego zgodnego poglądu ${ }^{20}$.

Bocheński mimo braku jednoznacznego stanowiska środowiska naukowego odnośnie tego, co kryje się za patriotyzmem, co on tak właściwie oznacza i z jakich elementów się składa, stara się wyjaśnić większość wątpliwości. W pierwszej kolejności należy przedstawić to, w jaki sposób filozof odpowiada na, moim zdaniem, podstawowe py-

19 J. Bocheński, Ku filozoficznemu myśleniu - wprowadzenie do podstawowych pojęć filozoficznych, Warszawa 1986, s. 46.

$20 \mathrm{~J}$. Bocheński, O patriotyzmie, [w:] J. Sadowski (red.), Oblicza patriotyzmu, Kraków 2009, s. 61. 
tanie, a mianowicie, czym tak właściwie jest obiekt patriotyzmu - ojczyzna:

Pod nazwą „ojczyzna” rozumiemy [...] naród wraz z zamieszkanym przez niego terytorium. Naród natomiast pojmujemy nie tylko jako zbiór jednostek obecnie żyjących, lecz przede wszystkim jako społeczeństwo odpowiedzialne za rozwój i szerzenie specyficznych wartości (kultury), stanowiących jego wkład do kultury ogólnoludzkiej. Słowem „miłość” oznaczamy nie uczucie, ale mocne nastawienie woli, która chce dobra ojczyzny21.

Widać, że tutaj także nie ma jednoznacznej odpowiedzi, gdyż „ojczyzna" zawiera w sobie również kilka elementów, takich jak: naród, terytorium, czy kultura. Dlatego też również w rozważaniach nad ojczyzną u Bocheńskiego odnaleźć można nieco różniące się rozwinięcia tego pojęcia, uzupełnione i bardziej rozbudowane, niż cytowane przeze mnie wcześniej:

Zgodnie z teorią polską, ojczyzna jest przedmiotem ontologicznie złożonym, choć etycznie prostym. Nie jest więc ojczyzną ani sam kraj (choć etymologia zdaje się to sugerować), ani sama grupa ludzka (np. grupa Polaków współczesnych), ani tym bardziej samo państwo polskie, ani inne podobne przedmioty, ale to wszystko razem. Natychmiast nasuwa się pytanie, pod jakim kątem widzenia jest ten zespół różnorodnych rzeczy i cech ujęty, gdy mówimy o miłości ojczyzny - gdyż nie może ulegać wątpliwości, że cała kompilacja materialna ojczyzny nie zmniejsza w żadnym stopniu jedności formalnej patriotyzmu. Chodzi więc o ustalenie cechy, która sprawia, że do tych wszystkich przedmiotów odnosimy się jako do jedności, jedną prostą postawą, zwaną patriotyzmem ${ }^{22}$.

Bocheński wskazuje nie tylko na to co jest ojczyzną, ale również na to co nią nie jest. Zaznacza także, że choć etycznie jest prosta, to z punktu widzenia ontologicznego jest przedmiotem złożonym. Jasno wnioskować można także, że pojedyncze elementy składowe nie stanowią ojczyzny. Dopiero wszystko zebrane w całość staje się czymś, co możemy nazwać ojczyzną. Największy problem stanowi więc usta-

${ }_{21}^{21}$. Bocheński, De Virtute Militari - zarys etyki wojskowej, Kraków 1993, s. 21.

22 J. Bocheński, Patriotyzm, męstwo, prawość żołnierska, Warszawa-Komorów 1999, s. 10. 
Łukasz Cieślakowski - Patriotyzm według...

lenie cechy łączącej wszystkie te elementy, która pozwoliłaby jednoznacznie określić sposób, w jaki powinniśmy do owych pojedynczych rzeczy podchodzić, aby stały się całością.

Kolejnym, bardzo ważnym elementem „ojczyzny”, który został wymieniony także przez Bocheńskiego, jest naród. Podobnie, jak to miało miejsce w poprzednich wypadkach, jest to kategoria dość szeroka, która może być interpretowana w nieco inny sposób, w zależności od tego, co jest brane pod uwagę:

\begin{abstract}
Naród jest zespołem, grupą ludzi. Tym samym jest przedmiotem realnym, jednostkowym, a nie idealnym, ogólnym. Ten zespół jest zawsze związany z pewnym krajem. To związanie nie ginie $w$ wypadku wychodźstwa: wychodźca czuje się związany z krajem ojczystym tak długo, jak długo czuje się za członka danego narodu. To jest jedyna bodaj cecha wspólna wszystkim narodom. Inne znajdujemy tylko w pewnych, ale nie we wszystkich narodach. Na pierwszych miejscu wypada wymienić tutaj znajomość języka narodowego i przywiązanie do niego. Tej cechy jako charakterystyki brak tylko tam, gdzie istnieje wielość języków narodowych, albo język wspólny wielu narodom [...] Wreszcie należą tutaj obyczaje i swoisty odcień moralności. Do obyczajów należą m.in. pieśni i obrzędy, np. na Boże Narodzenie, i u wierzących także obrzędy religijne odprawiane na sposób przyjęty w danym kraju. Ten zespół cech, stosunek do kraju, mowa i obyczaj, charakteryzuje naród w podstawowym tego słowa znaczeniu. Można by nazwać to pojęcie narodu „ludowym”, jako że masy jego niewykształconych członków pojmują naród w ten właśnie sposób 23 .
\end{abstract}

Myśliciel podobnie jak przedwojenne stanowisko dotyczące patriotyzmu do zdefiniowana tej jego części, którą nazywamy narodem używa takich kategorii jak język, obyczaje, które po zapoznaniu się z powyższym fragmentem tekstu Co to znaczy być Polakiem, ośmieliłbym się włączyć w szerszą kategorię, która owe obyczaje (takie jak pieśni i obrzędy) obejmuje - mianowicie kultury oraz stosunek do kraju, w którym się przebywa. Jest to, jak sam autor wskazuje, „ludowe” pojęcie narodu. Nie jest to jedyne rozumienie „narodu” prezentowane przez Bocheńskiego. W książce Urlicha Schrade Międzywo-

${ }^{23}$ J. Bocheński, Co to znaczy być Polakiem?, [w:] J. Sadowski (red.), Oblicza patriotyzmu, Kraków 2009, s. 80-81. 
jenna polska myśl narodowa czytelnik może odnaleźć następujący fragment:

Przyjmując umiarkowanie realistyczną koncepcję społeczeństwa Bocheński uważał, że: Naród to taka grupa ludzi, których łączy z jednej strony wspólna rasa psychiczna, wspólne cechy charakteru i obyczaj oparty na wspólnych przeżyciach i wspomnieniach historycznych, z drugiej zaś strony wspólny cel: praca nad rozbudową, kultywowaniem, obroną i rozpowszechnianiem wspólnych wartości duchowych, owej specyficznej kultury narodowej, która naród określa i dla której naród żyje ${ }^{24}$.

Takie pojmowanie narodu przez Bocheńskiego (jak w swojej pracy wskazuje Schrade) pochodzi z jego Szkiców o nacjonalizmie i katolicyzmie polskim. Da się tutaj również zauważyć nawiązanie do myśli przedwojennej (chociaż Bocheński sam przyznawał, że nie był zgodny ze wszystkimi teoriami pochodzącymi z przywoływanego przeze mnie okresu). Mamy w tym przypadku do czynienia ze wspólnym działaniem, które dąży do osiągnięcia przez społeczeństwo, wspólnego i określonego celu. Ponownie przywołana zostaje również kultura, która została tutaj przedstawiona jako swoisty cel (stwierdzenie mówiące o tym, że społeczeństwo żyje dla kultury) i coś, co określa dany naród.

Po wszystkich nawiązaniach do kultury nie można pominąć tego, jaki stosunek miał do niej Bocheński; tego, gdzie ją osadzał i za wytwór czego ją uznawał. Obecnie znane jest grubo ponad sto różnych definicji, różnego rozumienia pojęcia „kultura”. Jest to pojęcie bardzo szerokie, gdyż po pierwsze, kulturę możemy podzielić na to, co ujmiemy jako cultura agri, do której zaliczymy, to co łączy się z rolnictwem, oraz bardziej filozoficznie cultura animi, która odnosi się do „uprawy umysłu”. Po drugie do kultury możemy zaliczyć każdy wytwór człowieka, czy każdą inną rzecz, na którą miał on wpływ. Bocheński stwierdza, że ta kultura, która wchodzi w skład patriotyzmu jest wytworem pewnych jednostek terytorialnych. Filozof pisze:

24 U. Schrade, Międzywojenna polska myśl narodowa, Kraków 2004, s. 130. 
Łukasz Cieślakowski - Patriotyzm według...

[...] wydaje się [...] ze kultura, najważniejszy składnik ojczyzny, jest zawsze dziełem pewnej określonej jednostki terytorialnej i społecznej, która jako taka znacznie większych nabywa praw do naszej służby niż pozostałe. W Polsce taką jednostką niezmiernie przewyższająca inne swoim znaczeniem kulturowym, a więc i wpływem na to czym jesteśmy i co za tym idzie, prawem do nas - jest Polska jako całość. To czym jesteśmy duchowo (a to jest czynnik w człowieku najważniejszy), jest w znacznej mierze jej zasługą; żadna rodzina, gmina, dzielnica, a także [...] Europa jako całość, nie mogą się równać z nią wpływem ${ }^{25}$.

Widać wyraźnie, że kultura jest tu ukazywana jako jeden z najważniejszych - jeśli nie najważniejszy element, który składa się na naszą ojczyznę. Wpływa ona nie tylko na to, jak postrzegamy nasz kraj matczyny, ale również na to kim jesteśmy. Wszelkie nasze cechy wypływają właśnie z kultury, wspomniane wcześniej obrzędy czy mowa. Ponadto, słusznie zauważa Bocheński, że ma ona wpływ nie tylko na to jacy jesteśmy zewnętrznie - jaka jest nasza fizjonomia, ale przede wszystkim wpływa na nasze życie wewnętrzne - duchowe. Nie ma nic ważniejszego niż to co ową kulturę tworzy czyli Polska - kraj, w którym żyjemy. Nie może się z nią równać nic innego (ani mniejszego jak rodzina, ani większego - jak cała Europa). Polska bowiem ma największe prawo do nas, bo to ona nas ukształtowała takimi jakimi jesteśmy - to właśnie zdaje się mówić Bocheński.

Myśl Bocheńskiego odnośnie narodu nie jest wolna od różnych nieścisłości i problemów logicznych, a także pozbawiona niektórych rozważań. Urlich Schrade wskazuje na to, iż:

Bocheński nie zauważył [...] że pojęcie narodu może być rozumiane dwojako; raz jego elementami są poszczególne narody (np. naród serbski, mongolski czy amerykański), a innym razem są nimi członkowie poszczególnych narodów (Serbowie, Polacy, Mongoli czy Amerykanie). W pierwszym przypadku elementami zbioru „naród” są społeczności ludzkie, a w drugim - poszczególne jednostki ludzkie. W jednym i drugim przypadku mamy do czynienia z różną sytuacją logiczną. W przypadku, kiedy elementami zbioru "naród” z przydawką, na przykład, polski są poszczególni Polacy, rzeczywiście trudno wskazać cechy przysługujące wszystkim Polakom i tylko Polakom. Nie jest

25 J. Bocheński, Patriotyzm, męstwo..., op. cit., s. 15 
bowiem prawdą, że językiem ojczystym każdego Polaka i tylko Polaka jest język polski, ani też, że każdy Polak i tylko Polak uznaje za swoją ziemię ojczystą obecne terytorium Polski, ani tym bardziej, że każdy Polak i tylko Polak pochodzi od jakiejś polskiej grupy etnicznej itd. Ale przecież może być tak, że wymienione cechy wzięte $\mathrm{w}$ izolacji nie przesądzają o przynależności narodowej, a przesądza o tym jakiś zbiór cech. Tego przypadku ojciec Innocenty Maria Bocheński nie rozważał26.

Schrade wskazuje także na to, że Bocheński nie zawsze jasno wypowiadał się na temat narodu - jego prace wykazywały pewne sprzeczności.

Dwupoziomowe pojęcie narodu, na którym Bocheński oparł swoje wywody, nie jest do końca jasne. Twierdzi on, że jest to pojęcie dwupiętrowe: etniczne (kraj, mowa, obyczaj) i ideowe (historia, kultura, ideologia). To pierwsze rzeczywiście określa naród, a drugie raczej kształt patriotyzmu - dobro ojczyzny. Jeżeli uznać, że są to warunki konieczne dla tożsamości narodowej, to do narodu należałaby tylko jego elita i to elita polityczna ${ }^{27}$.

Nie można zatem twierdzić, że do narodu nie należy nikt inny oprócz elit politycznych. Tak nie jest i to zdaje się być argumentowane także historycznie. Nie jest prawdą bowiem, że w ciągu naszej historii państwowości za naród uważały się wyłącznie wspomniane elity. Często bywała nawet przeciwnie. To przedstawiciele niższych sfer pielęgnowali z pietyzmem te wszystkie tradycje, które świadczą o narodowości.

\section{Wielowątkowość pojęcia patriotyzm}

Nie da się nie zauważyć, że patriotyzm jest pojęciem bardzo szerokim i nie da się go określić w łatwy i przejrzysty sposób. Próby jego zdefiniowania, teoretycznie kończące się sukcesem, z czasem przysparzają więcej wątpliwości niż na początku. W myśli Bocheńskiego

\footnotetext{
26 U. Schrade, Międzywojenna polska myśl..., op. cit., s. 125-126.

27 Ibidem, s. 167.
} 
Łukasz Cieślakowski - Patriotyzm według...

istnieje wiele wątków odnoszących się do patriotyzmu, który jak się okazuje niekoniecznie jest uczuciem. Sam Józef Bocheński pisał bowiem w następujący sposób:

Jako dział sprawiedliwości, patriotyzm ma przede wszystkim siedzibę nie w uczuciu, ale w woli: jest pewną sprawnością woli, pozwalającą na energiczne i stosunkowo łatwe pełnienie obowiązków wobec ojczyzny. Nie jest on więc uczuciem - aczkolwiek uczucie patriotyczne może walnie się przyczyniać do jej należytego działania. Nie ten jest więc dobrym patriotą, kto ma najgorętsze uczucia patriotyczne, ale ten, kto potrafi najlepiej swój obowiązek patriotyczny spełnić, innymi słowami - ten, kto ma najsilniejszą po temu wolę 28 .

Widać z powyższego, że potoczne pojęcie patriotyzmy jest dość płytkie, a zagłębiając się w jego struktury napotykamy na coraz nowsze problemy z nim związane. Problemy które trzeba wyjaśnić aby uskuteczniać to, co przez wieki społeczeństwo starało się uskuteczniać - miłość do własnego kraju.

Wiele powstało definicji patriotyzmu, wiele można o nim powiedzieć - nie można jednak stwierdzić, że on nie istnieje. Wręcz przeciwnie - istnieje i trzeba go pielęgnować. Trzeba tylko pamiętać, aby nie przekształcił się on w coś zgoła innego, co nie jest dobre:

Miłość ojczyzny i rodaków bynajmniej nie jest zabobonem, ale cnotą godną pielęgnowania, podobnie jak miłość rodziny itd. Ale z patriotyzmem łączą się dwa wzajemnie przeciwne zabobony: jeden z nich przywiązuje do miłości ojczyzny zbyt dużą wagę i czyni z patriotyzmu nacjonalizm, a więc zabobon. Drugi, przeciwny mu, także miesza patriotyzm z nacjonalizmem, a nawet $\mathrm{z}$ rasizmem i potępia go jako taki ${ }^{29}$.

\section{Obowiązki wobec ojczyzny}

Rzeczą jasną zdaje się być, że podstawowym obowiązkiem wobec ojczyzny jest jej obrona, nawet obrona za wszelką cenę, czyli poświęcenie własnego życia. Jest ona dobrem najwyższego rzędu, więc nie

\footnotetext{
28 J. Bocheński, Patriotyzm, męstwo..., op. cit., s. 12.

29 J. Bocheński, Sto zabobonów, Kraków 1994, s. 96.
} 
powinniśmy wahać się oddać to wszystko, co posiadamy. Zastanowić się jednak należy, co owe obowiązki (nie tylko poświęcenie życia) determinuje - co stanowi ich podstawę?

Patriotyczne obowiązki wobec ojczyzny opierają się na dwu różnych cnotach. Obowiązki wobec ojczyzny traktowanej jako dawczyni wszystkiego tego, czym jesteśmy wspiera się na cnocie prawości, a traktowanej jako pewien nam powierzony odblask chwały Bożej na ziemi - na cnocie miłości. Patriotyzm jako dział sprawiedliwości zobowiązuje nas przede wszystkim do spłacenia długu wdzięczności za otrzymane dary życia i człowieczeństwa. Jest to dług stały, którego tak jak dług w stosunku do rodziców, spłacić niepodobna, stąd stąd też winniśmy dać ojczyźnie tyle, na ile nas tylko stać30.

Jak widać, wyróżnić w myśli Bocheńskiego można dwie ścieżki, które bazują na dwóch odmiennych cnotach. Głębiej wyjaśnia on to w dziele $O$ patriotyzmie, w którym to wskazuje na dwie drogi, dwie rożne cnoty determinujące nasze obowiązki wobec ojczyzny.

Na pierwszej drodze mamy do czynienia z cnotą podobną do cnoty religii, tzn. miłości rodziców i wdzięczności. A mianowicie chodzi tu o obowiązek zaciągnięty przez nas wobec ojczyzny, której zawdzięczamy, pośrednio lub bezpośrednio, niemal wszystko czym jesteśmy: ideały, w które wierzymy, cnoty, które posiadamy, naszą kulturę estetyczną, nasze specyficzne zwyczaje, wychowanie, aż do cech biologicznych. Tak pojęta „miłość ojczyzny” jest poddziałem prawości, nie miłości właściwej, i oczywiście, obowiązuje w sposób podobny do pierwszej.

Na drugiej drodze chodzi o zrządzenie woli Bożej, które uczyniło nas współodpowiedzialnymi za pewien odblask Boskiej świetności, przejawiającej się we wszystkim co ojczyzną nazywamy, a więc w krajobrazie, dziejach, tradycji, religii, obyczaju i sztuce ojczystej ${ }^{31}$.

Dodatkowo, z rozpraw myśliciela wynika, że także wielkim obowiązkiem wobec ojczyzny jest wychowanie do miłości kraju matecznego. Koresponduje to także $\mathrm{z}$ tym, co można było zaobserwować w przypadku cytowanych przedwojennych podręczników odnoszących się do patriotyzmu, miłości do ojczyzny oraz wychowania patriotycznego właśnie. Bacząc na to, co Bocheński pisał wcześniej i to, co

\footnotetext{
30 Ibidem, s. 145.

31 J. Bocheński, 0 patriotyzmie, op. cit., s. 63.
} 
Łukasz Cieślakowski - Patriotyzm według...

wchodzi w skład patriotyzmu oraz ojczyzny, filozof w swoim dziele De Virtute Militari - zarys etyki wojskowej, odnoszącym się także do patriotyzmu, wspomina co takiego powinno wchodzić w wychowanie patriotyczne i czego (oraz dlaczego) powinno się nauczać, żeby zaszczepiać umiłowanie ojczyzny. Wyjaśnia on także, jak sprawić, by obowiązki wobec ojczyzny wykonywane były sumienniej i z większym poświęceniem:

Wychowanie miłości ojczyzny objąć powinno zarówno rozum i wolę, jak drugorzędnie pamięć, wyobraźnię i uczucia. Nie można dzielnie walczyć o coś, czego się nie zna i nie ocenia należycie. Stąd podstawą miłości ojczyzny jest dobra znajomość swojego kraju, dziejów, kultury i wartości, których jest nosicielem ${ }^{32}$.

Patriotyzm w myśli Bocheńskiego ściśle związany jest z kulturą narodową, którą (jak nieraz podkreślał) trzeba pielęgnować. Ma ona także wpływ na to, jaki ów patriotyzm będzie. Czynniki kulturalne stanowią bowiem istotny składnik wspomnianego patriotyzmu.

[...] na pierwszym miejscu stoją i znakomicie przeważają nad innymi czynnikami - kulturalne. Można to udowodnić i empirycznie i a priori. Empirycznie, przez wskazanie na wielu ludzi urodzonych poza granicami Polski, a jednak przyznających się całą duszą do polskości - albo na innych, którzy z obcych rodziców pochodzą, a jednak, żyjąc długo w Polsce, za Polaków szczerze się zaczynają uważać. A priori rzecz jest również oczywista, jeśli zważymy, że aczkolwiek człowiek nie jest tylko duchem, to jednak jest przede wszystkim istotą duchową i w jego życiu etycznym główną rolę odgrywają czynniki duchowe - a więc kultura ${ }^{33}$.

Z powyższego cytatu wywnioskować można, że zdaniem Bocheńskiego to właśnie kultura narodowa - jako czynnik duchowy, ma istotny wpływ na ludzkie odczucia patriotyczne. To właśnie kultura w jakiej wzrastamy (czy przez wychowanie przez rodziców, czy za sprawą przenikania kultury ze środowiska, w którym żyje i funkcjonuje dana jednostka). Zdaniem Bocheńskiego to właśnie kultura -

32 J. Bocheński, De Virtute Militari..., op. cit., s.22.

33 J. Bocheński, Ku filozoficznemu myśleniu - wprowadzenie do podstawowych pojęć filozoficznych, Warszawa 1986, s. 73. 
przyznawanie się do danej kultury, jest bardziej wiążącym ludzi w odczuciach patriotycznych, aniżeli „suchy” wpis w paszporcie określającym obywatelstwo:

Choć więc nie będzie to zupełnie ścisłe, możemy powiedzieć, że przyznanie się do określonej ojczyzny jest przede wszystkim przyznaniem się do pewnej kultury narodowej. Powiedzenie to jest w każdym razie znacznie trafniejsze, niż np. formalistyczne określenie narodowości przez obywatelstwo (pospolite u Francuzów) i niż rasizm niemiecki, będący poza tym, w świetle wyników antropologii polskiej, teorią sprzeczna z wszelkimi danymi faktycznymi ${ }^{34}$.

\section{Zakończenie}

Kończąc muszę zaznaczyć, że była to próba przedstawienia poglądów Józefa Marii Bocheńskiego na temat patriotyzmu oraz samej sylwetki tego znakomitego polskiego filozofa. Wiele jest jeszcze wątków dotyczących patriotyzmu, które nie zostały przeze mnie poruszone. Jednak mogę jednoznacznie stwierdzić, że poglądy Bocheńskiego dotyczące patriotyzmu wywodzą się z patriotycznej myśli dwudziestolecia międzywojennego. Prezentowana myśl filozofa i założenia dotyczące patriotyzmu oraz wychowania patriotycznego wywodzą się właśnie ze wspomnianego i po części przeanalizowanego przeze mnie okresu. W moim tekście porównałem niektóre ze wczesnych poglądów Józefa Marii Bocheńskiego z ówczesnymi wytycznymi do kształcenia obywatelskiego i patriotycznego. Widać także wyraźnie wpływ rodziny na poglądy Bocheńskiego, co było można zauważyć po przeanalizowaniu biografii myśliciela, która ściśle wiąże się atmosferą domu rodzinnego Bocheńskich, a także wartości przekazywanych przez rodziców. Jak pisze Zbigniew Dziemianko odnośnie wychowania do miłości ojczyzny: „w szczególności chodziło o to, aby rodzina wytwarzała atmosferę wychowania patriotycznego sprzyjającą pracy wy-

\footnotetext{
34 Ibidem.
} 
Łukasz Cieślakowski - Patriotyzm według...

chowawczej organizacji przysposobienia wojskowego i wojska"35. Zatem wychowanie rodzinne stanowiło podwalinę pod pracę tworzonych organizacji proobronnych - widać, iż sam Bocheński przesiąkł takim podejściem do znaczenia rodziny gdyż sam je reprezentował w swoich tekstach. Wyraźny wpływ na poglądy Bocheńskiego (przynajmniej te pochodzące $\mathrm{z}$ okresu, nazwijmy to przedkomunistycznego) wywarła także służba wojskowa i wojna roku 1920. Zauważyć można to w tekstach opublikowanych w pracy pod tytułem Patriotyzm, męstwo, prawość żołnierska, które pochodzą z 1939 roku, w których to zaznacza, że:

noszenie munduru wiąże się ze swoistą ascezą: $\mathrm{z}$ wieloma wyrzeczeniami oraz ciężkimi próbami charakteru i zasad moralnych, zwłaszcza podczas wojny. Wojna zaś, jak każda sytuacja ekstremalna, naprawdę pokazuje, ile wart jest człowiek - ujawnia tchórzy, zdrajców i zbrodniarzy, a z drugiej strony bohaterów i ludzi szlachetnych ${ }^{36}$.

Kończąc muszę postawić tezę, do której doszedłem analizując przedstawione powyżej teksty. Bocheński, mimo wielu przemian poglądów, spowodowanych zmieniającą się sytuacją polityczną, gospodarczą oraz wieloma innymi czynnikami pozostał przesiąknięty tym, co funkcjonowało w czasach jego młodości. Przez wiele lat myśl Bocheńskiego ewoluowała, przekształcała się - jednak (parafrazując myśl Bocheńskiego dotyczącą wartości i ich części „stałych”) trzon dotyczący patriotyzmu w jego poglądach pozostał taki sam, jakim ukształtowało go dwudziestolecie międzywojenne.

\section{Bibliografia:}

Baranowski M., Pedagogika do użytku seminaryów pedagogicznych i nauczycieli szkół ludowych, Warszawa-Lublin-Łódź-Poznań-Kraków 1921.

Bocheński J., De Virtute Militari - zarys etyki wojskowej, Kraków 1993.

35 Z. Dziemianko, Kształtowanie postaw obywatelskich i patriotycznych przez polskie organizacje przysposobienia wojskowego $w$ dwudziestoleciu międzywojennym, „Przegląd Naukowo-Metodyczny. Edukacja dla Bezpieczeństwa” 2008, nr 1, s. 70-75.

36 A. Danek, Podręcznik katolickiego żołnierza, „Rycerz Lepanto” 2007, nr 2, s. 9. 
Bocheński J., Ku filozoficznemu myśleniu - wprowadzenie do podstawowych pojęć filozoficznych, Warszawa, $1986 \mathrm{r}$.

Bocheński J., Patriotyzm, męstwo, prawość żołnierska, Warszawa-Komorów 1999.

Bocheński J., Sto zabobonów, Kraków 1994.

Bocheński J., Wspomnienia, Kraków 1994.

Danek A., Podręcznik katolickiego żołnierza, „Rycerz Lepanto” 2007, nr 2, s. 9.

Dziemianko Z., Kształtowanie postaw obywatelskich i patriotycznych przez polskie organizacje przysposobienia wojskowego $w$ dwudziestoleciu międzywojennym, „Przegląd Naukowo-Metodyczny. Edukacja dla Bezpieczeństwa” 2008, nr 1.

Encyklopedia Powszechna Ilustrowana, Tom III, Warszawa 1911.

Kosiński W., Pedagogika podręcznik dla wychowawców i nauczycieli, PoznańWarszawa, 1918.

Policki K., Filozofia człowieka we wczesnej twórczości J. I. M. Bocheńskiego OP, Wrocław 2005.

Sadowski J., Oblicza patriotyzmu, Kraków 2009.

Schrade U., Międzywojenna polska myśl narodowa, Kraków 2004. 